\title{
خيري الهنداوي \\ (حياته ودوره الفكري والسياسي دراسة تأريخية)
}

19OV-1110

د. حسن صالح مهاي المياح

كلية التربية-جامعة واسط دهاع دهاح

المقدمـــة

لابد من دراسة سيرة السيد خيري الهنداوي لكونه يمثل احد قادة الفكر السياسي والأدبي في العراق خلد القرن العشرين. كان فكره الأدبي أداة من أدوات الحماسة وحث الناس على الثثرة والجهاد وبقيت قواعده اسلامية على الرغم من ان انتيار الوطني بدأ قويا. كانت حياة الهنداوي في طور سياسي مضطرب وفكري ثائر ، غير مستقر فاضطررت الاستعانة بملفه الخاص

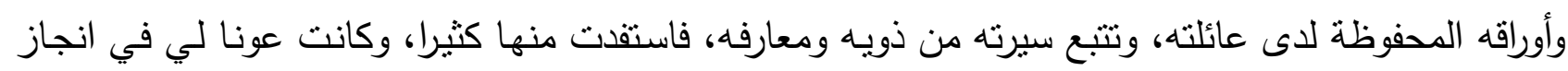
هذا البحث. تتاول الفصل الاول ولادته ونشأته الاولى ونشاطاته المبكرة. اما الفصل الثاني فتطرق الى موقفه من الانكليز

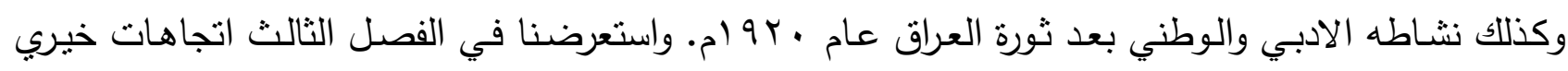
الهنداوي السياسية بعد احالته على التقاعد.

\section{الفصل الاول}

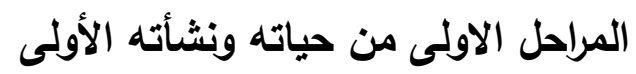

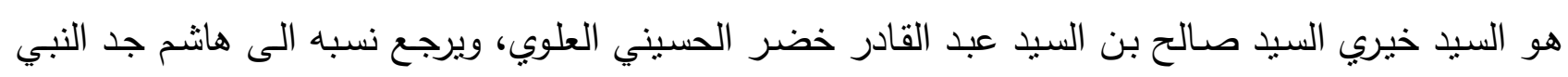

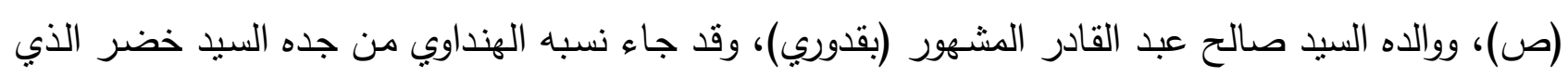

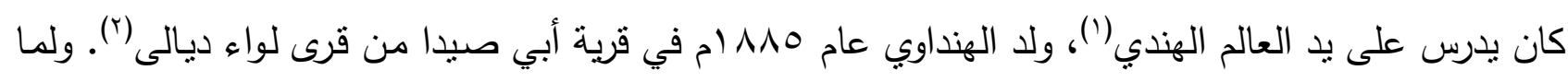

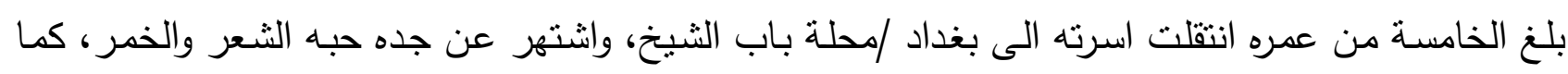
كان والده يحثه على دراسة الادب والثعر واللغة العربية والقران الكريم(").

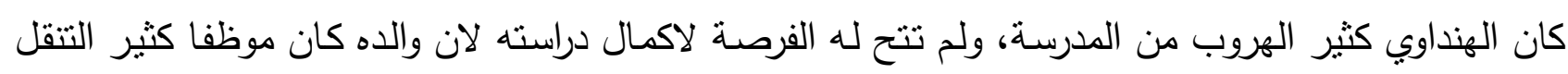

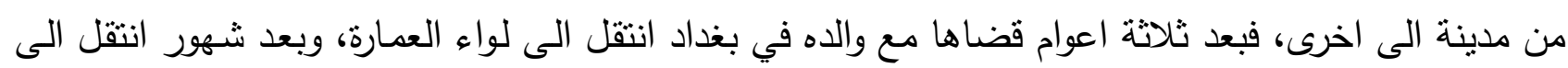

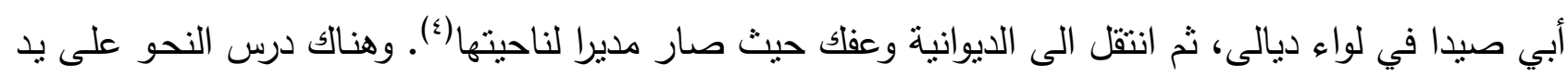

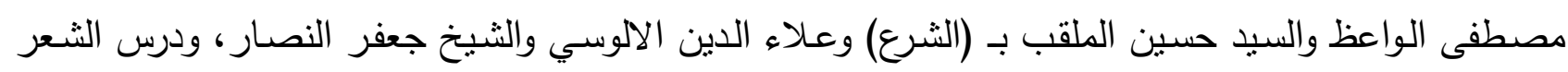

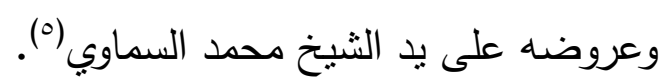




\section{العدد السابع}

اثرت الحياة الفكرية وتياراتها والنزاع بينهما في حياة خيري الهنداوي، واخذ يتابع هذه التغيرات والاحداث الادبية

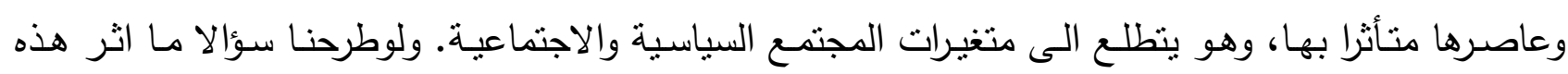
التفاعلات في حياة الهنداوي ؟ فلابد ان نبدأ منه:كانت ولادته في القرن التاسع عشر، وتثبع باراء هذا القرن وروحه وافكاره وتياراته وشب عليها، وعاش في بيئة اعتادت على اقامة الثعائر الحسينية(7). ظهرت عبقريته الادبية من خلال مقالاته المنشوره في الجرائد كالمقتطف، وصدى بابل، ولواء الاسلام، والرقيب،

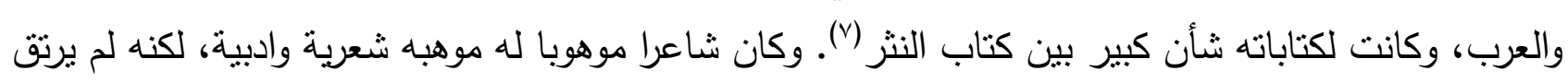
الى درجة الفحول من الثعراء والادباء (^).

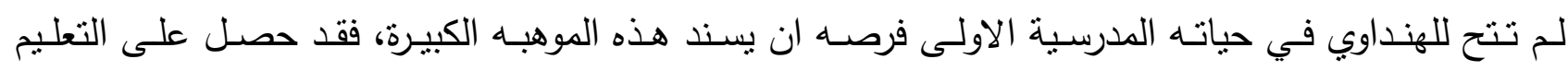

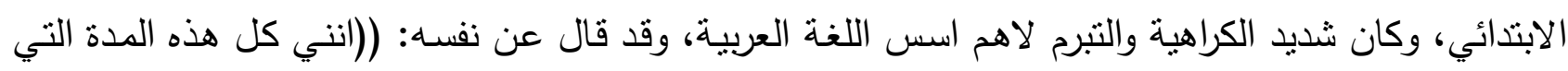

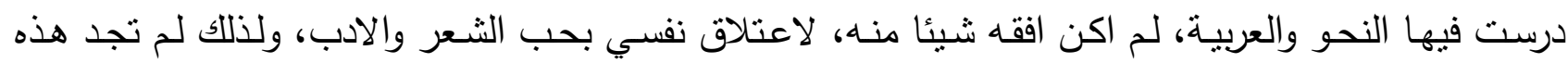
القواعد لها محلا في دماغي. ....(9).

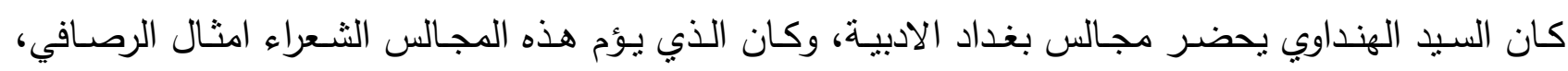

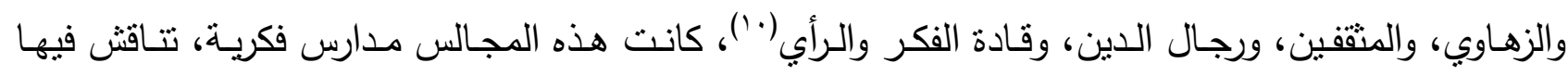
القضايا الادبية والسياسية(')

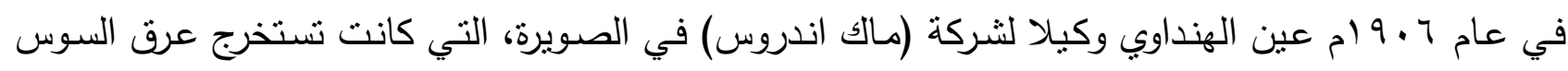

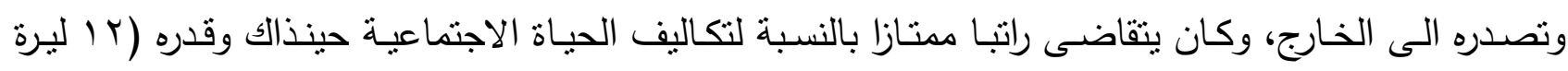

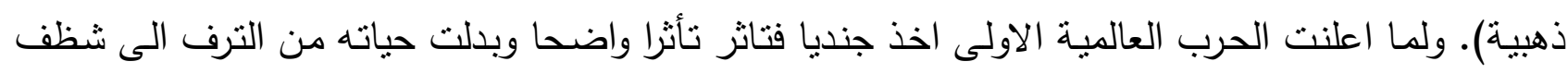

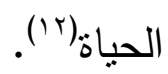

وقد كان العامل النفسي اهم مؤثز في نفسه، ثم ان الفساد الاداري والمالي الذي انتشر في الدوله العثمانية، اخذ

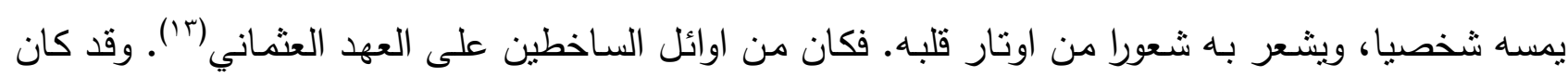

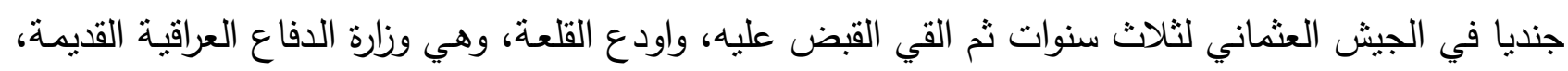
وقد بقي مسجونا فيها (1). وقد اراد العثمانيون التخلص منه وقتله والقاء جثته في نهر دجله، لان الجيش البريطاني بدأ يقترب من بغداد،

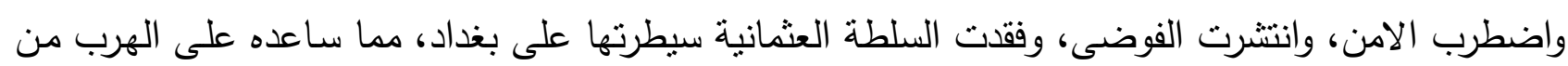
سجنه والاختفاء في محلة المهديه (10). مانمح شخصيته و صفاته.

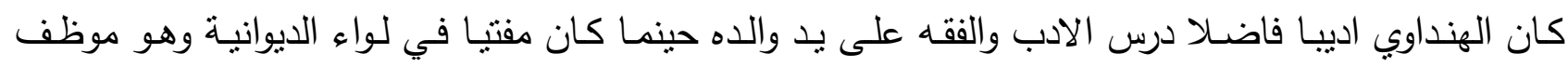

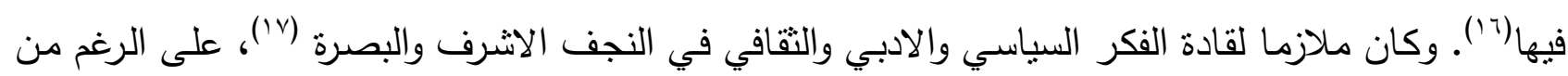
ثقافته القليله في علوم اللغة العربية(')، وكان كارها للهيأة العسكرية (19). 


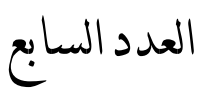

كان الهنداوي رهيف الحس، كريم الخلق، ومن كانت هذه صفاته فانه يحب الناس بقلبه، وكان مثالا طيبا لجميع

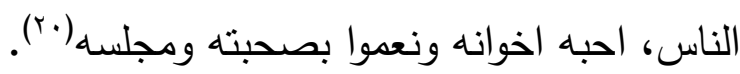

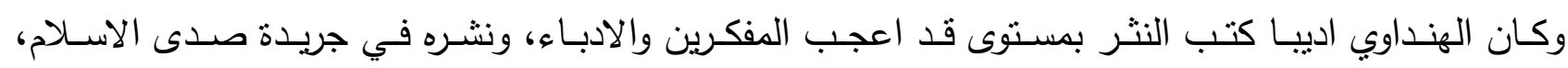

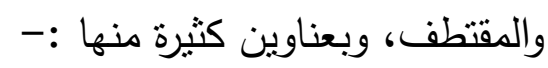
الحرب والاسلام، الانتباه الاسـلاهي، العلم والعمل، فثل آمال الانكليز في العراق، بغداد اليوم (باد). وقد أسهم

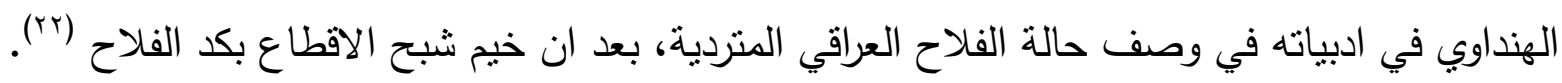

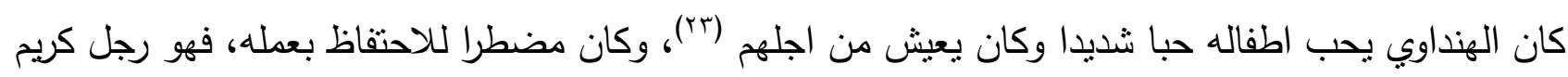

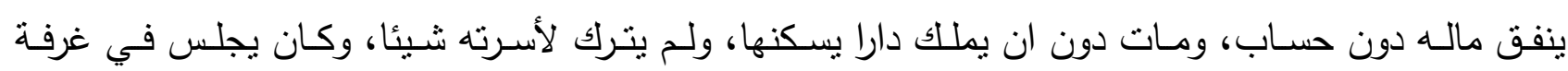

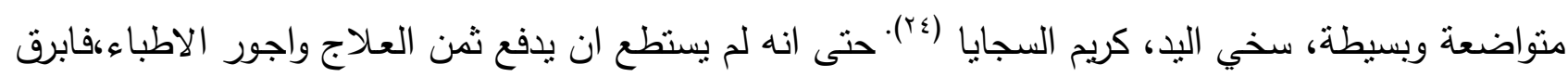

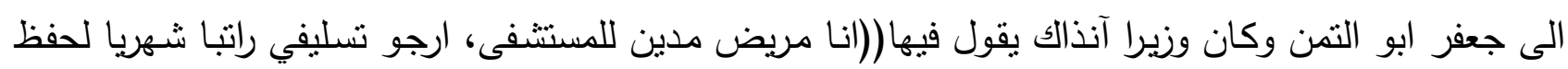

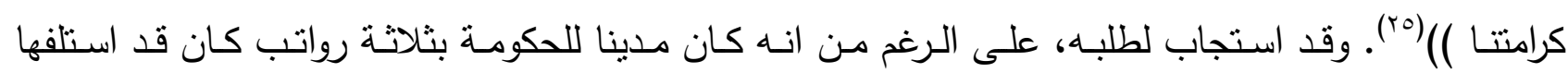

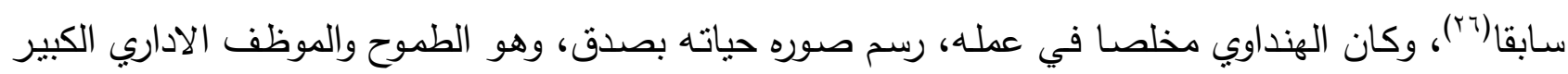

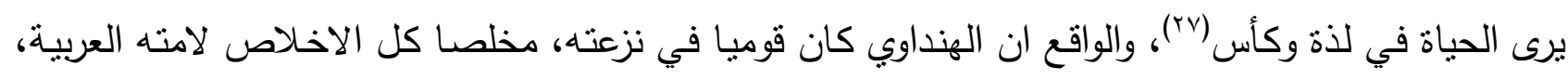

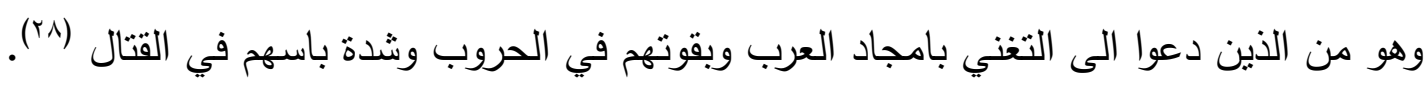

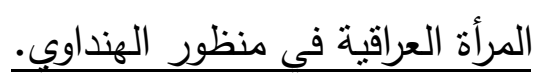

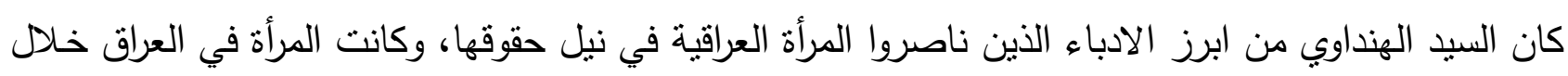

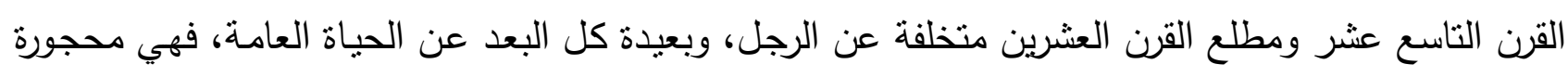
في داخل الدار، ولم يكن لها رأي مسموع حتى في زواجها (r9). كانت مشكلة المرأة من المشكلات التي عالجها المفكرون المتحررون، وكان الهنداوي منهم في في فكره التقدمي(·r)،

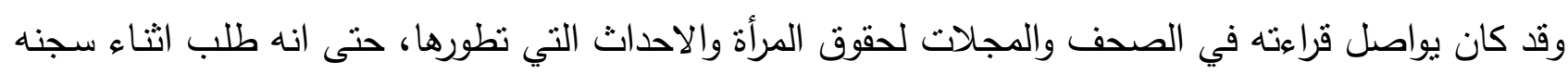

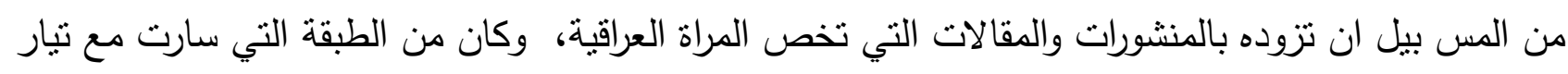

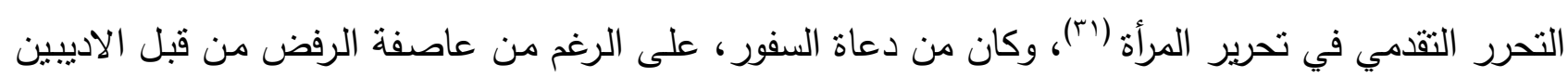
عبد الحميد الازري و جواد الحسيني (rr).

\section{الفصل الثاني}

نشاطاته ومواقفه الوطنية من السياسه البيرطانيه

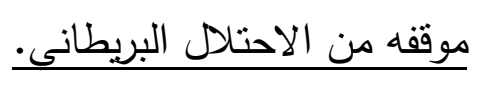

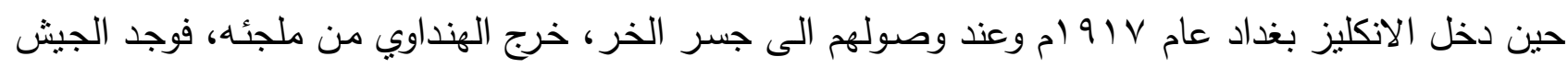

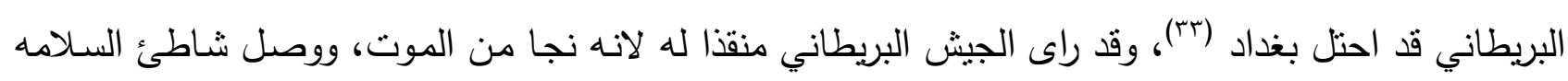

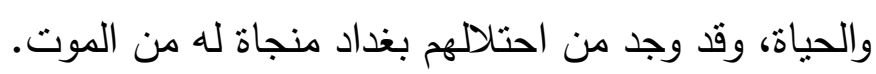




\section{العدد السابع}

بدأ الهنداوي يتفحص الامور بعد ان وطئ الارض قوم لم يعرف عنهم شيئأ، واخذ الانكليز يتقربون من اليهود

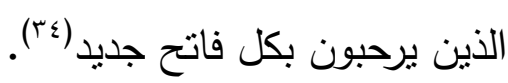
ساء امر اليهود الهنداوي وخشي ان يتسلموا زمام الامور ، فاسرع واتصل بالسيد عبد المجيد الثناوي احد قادة

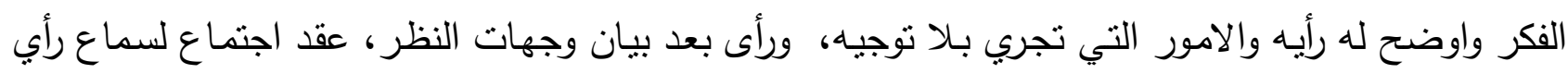

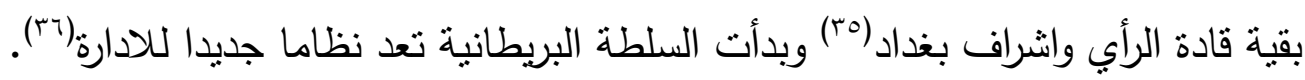

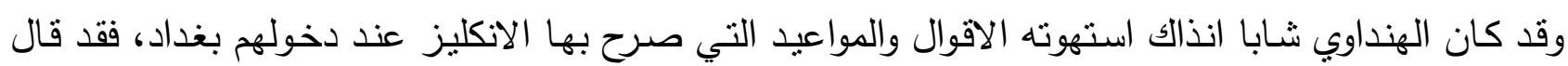

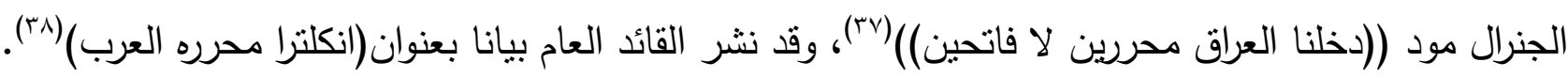

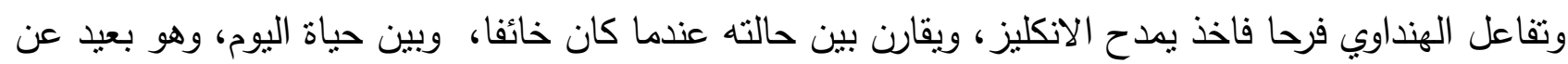

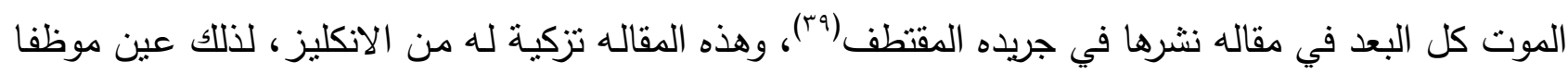

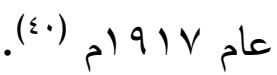
بدأت الامور تتوضح، وبدأ العراقيون يحسون بوطأة الاحتلال الانكليزي، وظهر جليا ان تلك الثعارات التي نادى بها المحتلون بعيده كل البعد عن الواقع.

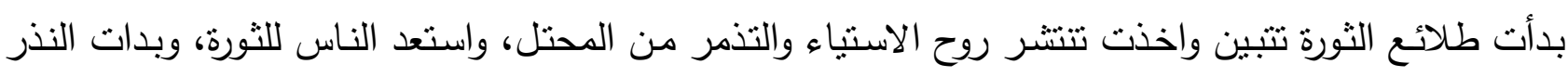

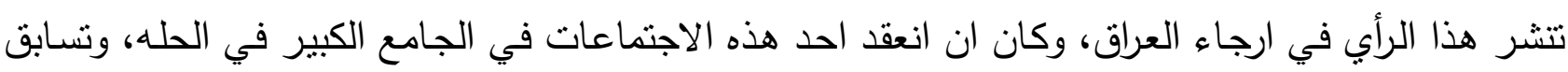

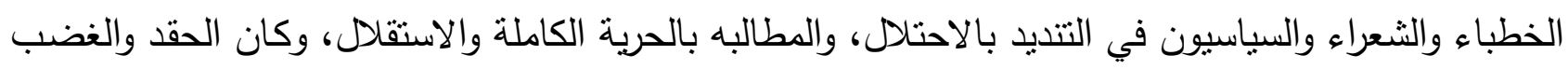

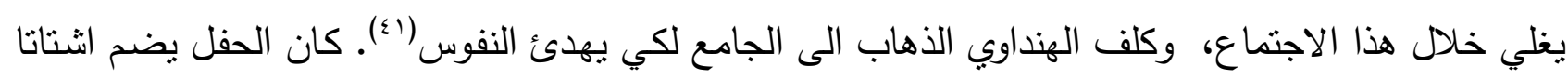

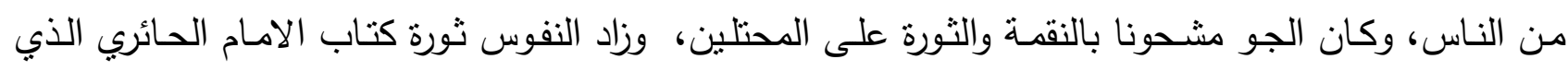

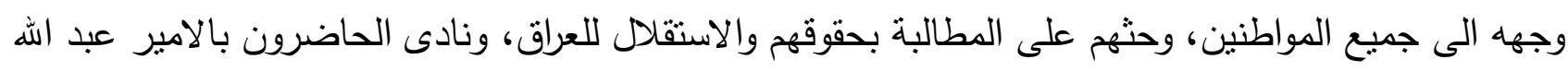
ملكا على العراق( (\$r). في هذا الجو الهتوتز والنفوس الثائرة، ذهب الهنداوي ليهدئ الثائرين، ويخفف من الثورة، وكان في نفس الهنداوي

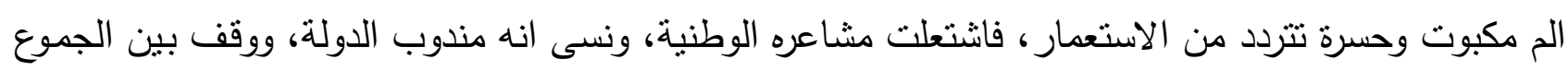

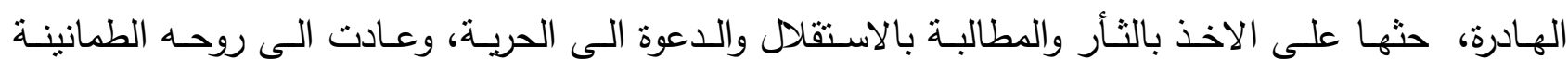

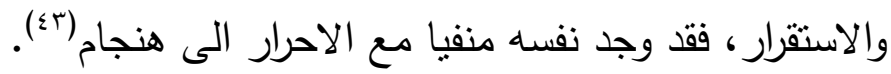
فوصفها بقوله قذفونا خلف البحار بأرض فوله

\section{عندها يلعن الصبوح الغبوقا(ءء)}

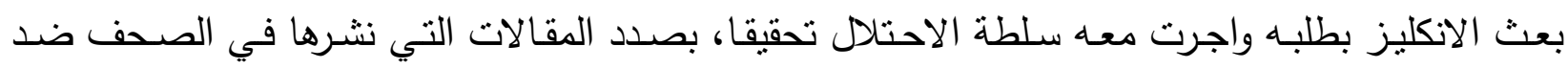

السلطة الحاكمة، وكتب الحاكم السياسي في بغداد الى الحاكم السياسي في الثنامية والكوفه يقول فيها (...

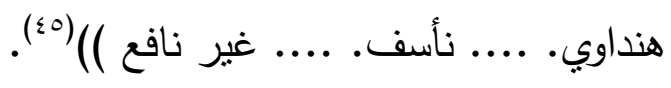

وبعد ذلك نقل الى عدة مناطق آخرها معاون مدير مال العزيزية باشراف موظف بريطاني (T؛؛). 


\section{العدد السابع}

عند الرجوع الى ملف السيد الهنداوي عثرنا على رسالة موجهة الى السلطة البريطانية في بغداد، يشكو فيها من

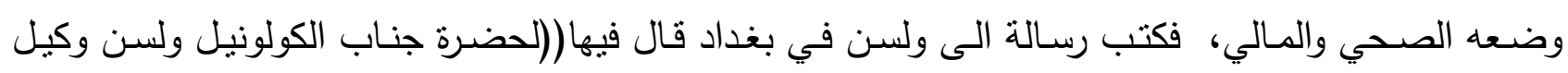

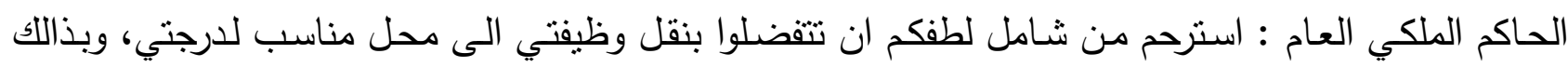

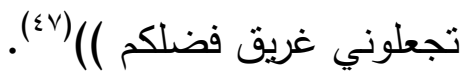

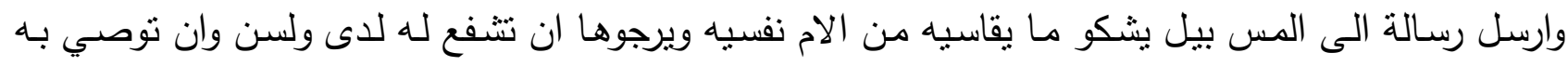

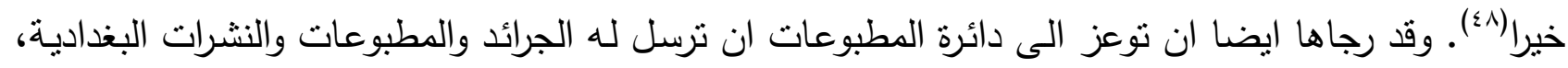

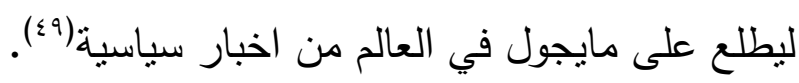

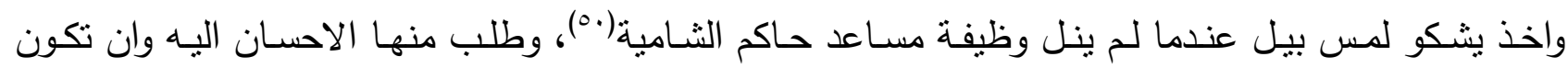
بجانبه، وطالب نقله الى عمل يليق به، او نقله الى بغداد، واذا لم يجد لطلبه قبولا فيرجوها ان نتشير عليه حتى بنى يقدم استقالته من خدمة الحكومة (10). بعد عودته من المنفى عين في (مايس عام ب ب 9 (ام قائممقام قضاء الثامية وبعد تعيينه صار مستقرا نفسيا،

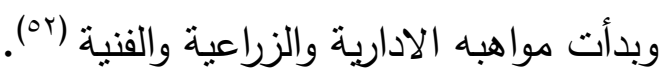

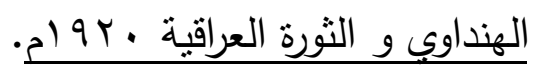

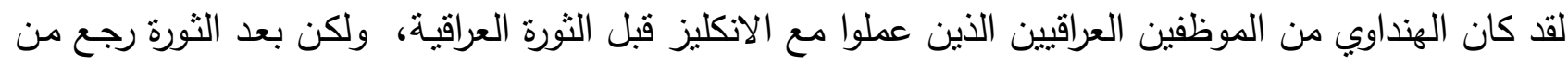

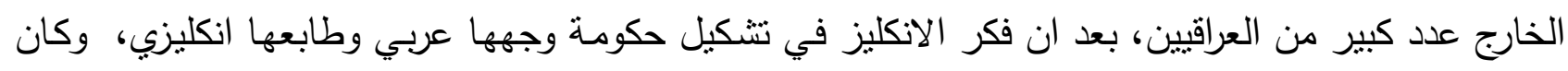

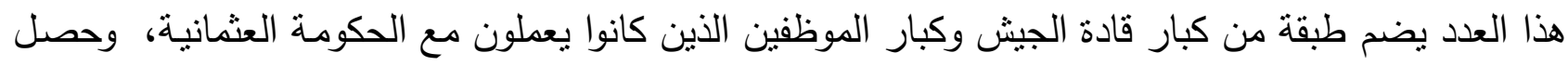

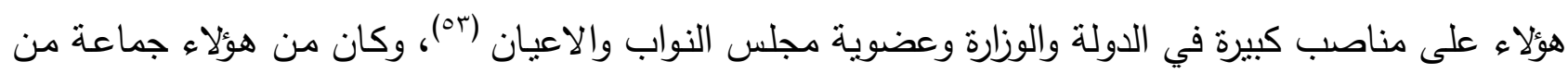

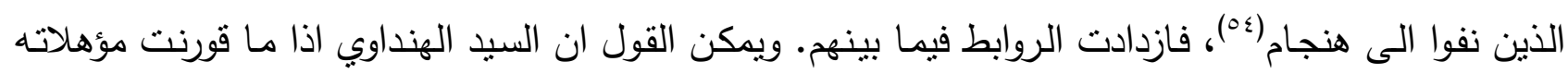
العسكرية والعلمية والثقافية بزملائه، فاننا نجد الكثير منهم قد نقدموا عليه علميا او عسكريا او اداريا، ولم يكن الهنداوي غير جندي اجباري عندما دخل الانكليز بغداد، ولم تتح له الفرصه لإكمال دراسته العالية.

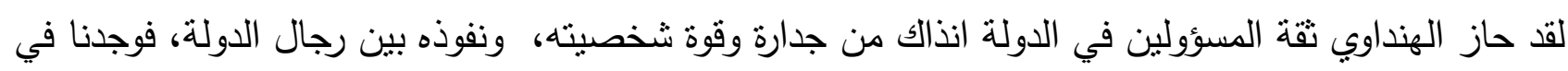

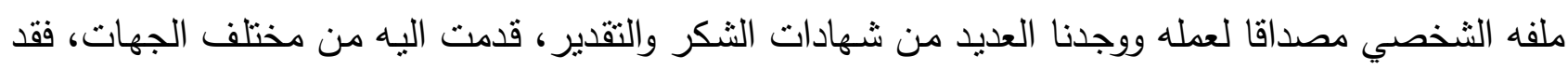

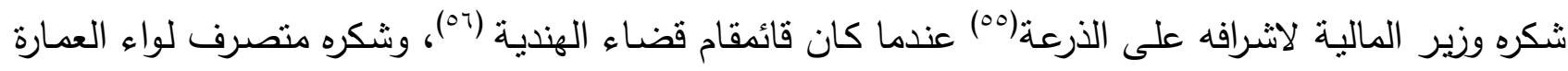

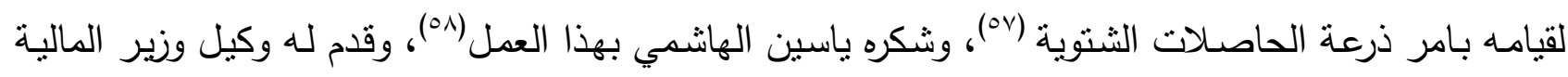

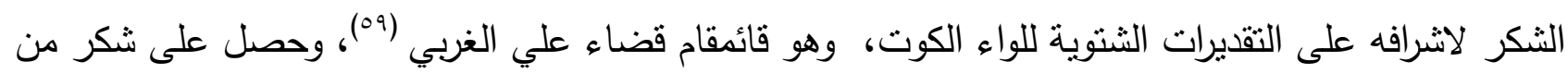

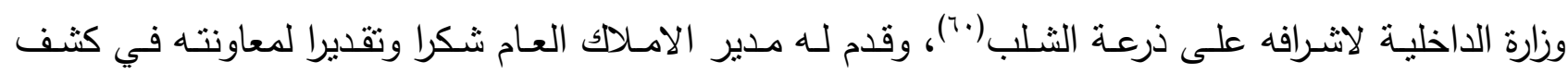

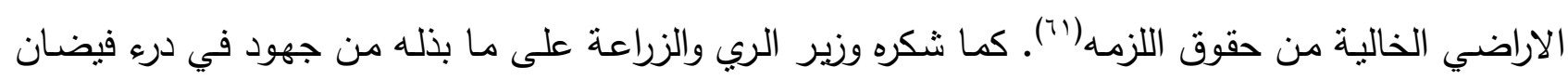
نهر دجلة(Tr).

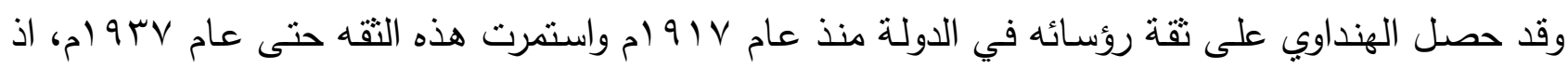

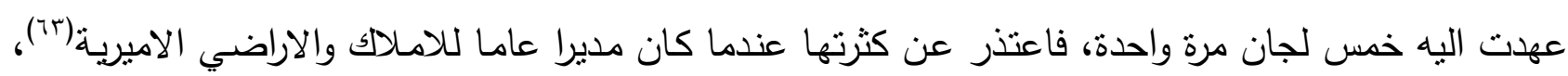




\section{العدد السابع}

وعلى اثره تم اعفاؤه من منصب مدير الاملالك والاراضي وعمل منصرفا للمنتقك ثم الكوت، وبعد وفاة الملك

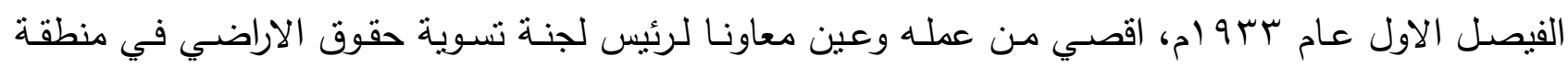

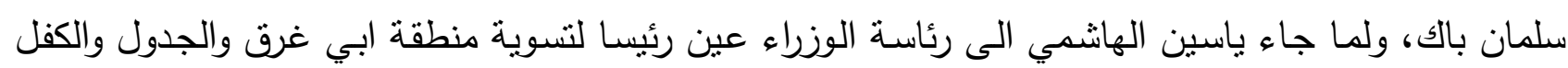

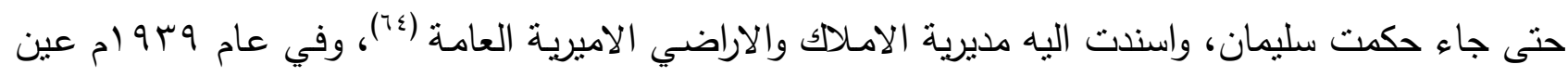

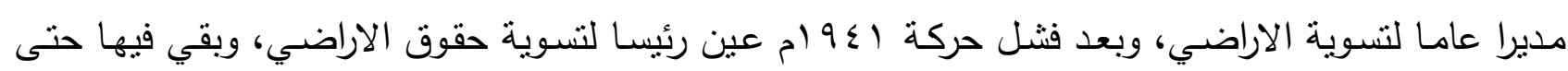

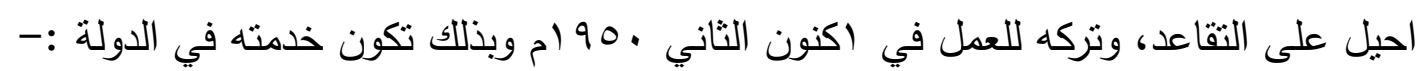

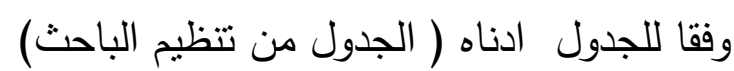

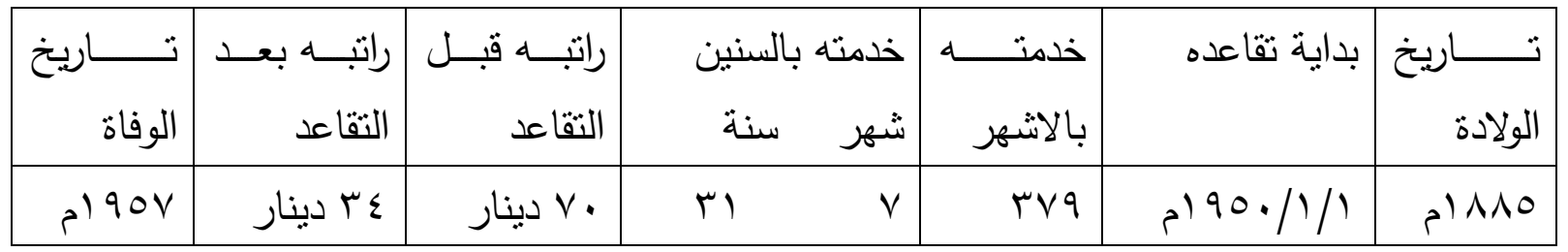

\section{الفصل الثالث}

\section{اتجاهاته السياسيه ومراحل حياته الاخيرة}

نشاطه السياسى بعد ثورة العشرين.

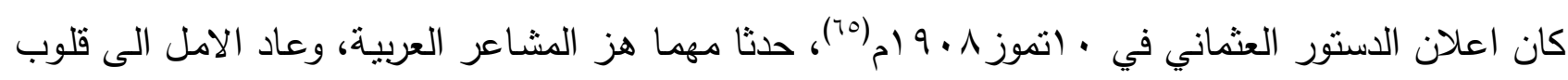

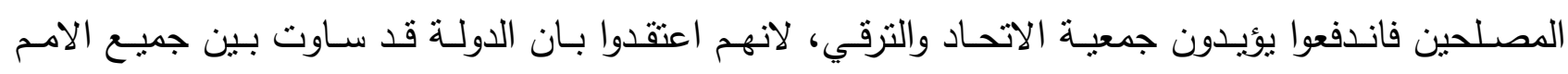

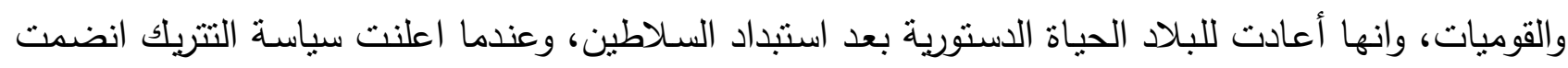

الاسر العربية الى حزب الائتلاف المناوئ لجمعية الاتحاد والترقي (17).

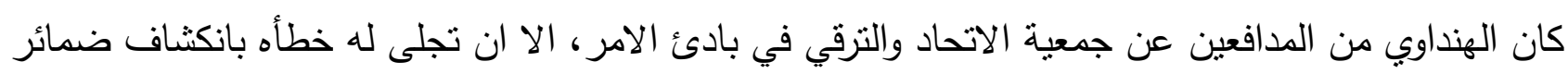

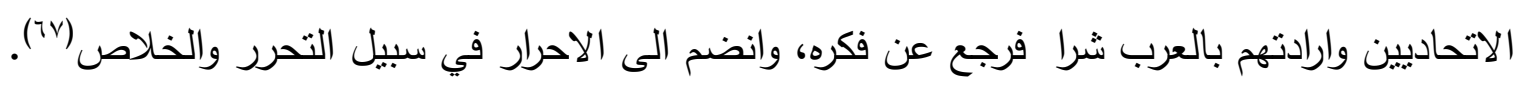

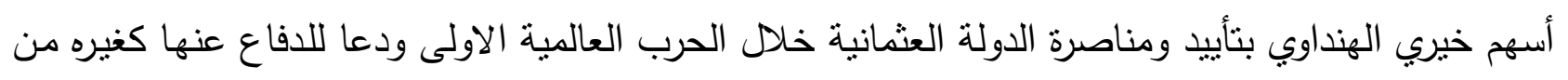

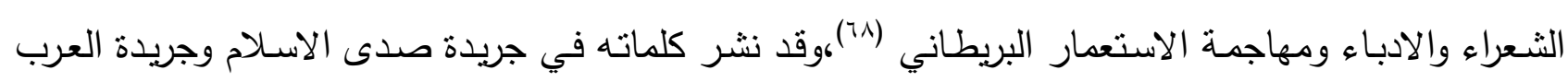
ومجلة المقتطف باسماء مستعارة (79). كان الهنداوي من المؤيدين لدعوة طالب النقيب لارتقائه عرش العراق، اذ كانت السياسة البريطانية ضد فكرة النقيب (v•)

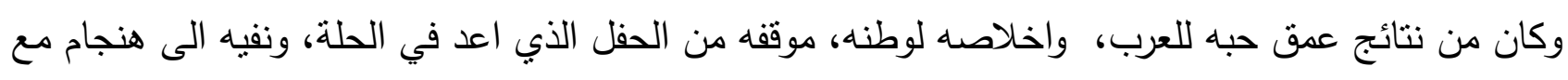

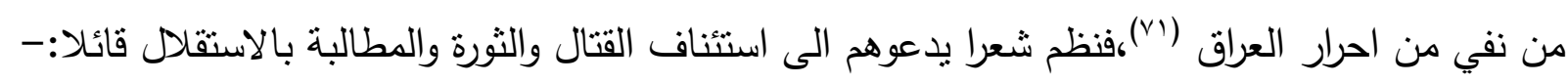
وبك لا ارتضي الحياة بذل

\section{قم فمزق أهابها تمزيقا}


العدد السابح

مجلة كلية التزبية

فهبي وحلقي تحليقا (Vr)

وبعد الثورة العراقية، وما جر الاستعمار على البلاد من ويلات، فقد ثقته بالبريطانيين ووجدهم على غير ماكان

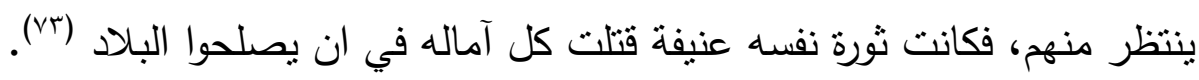

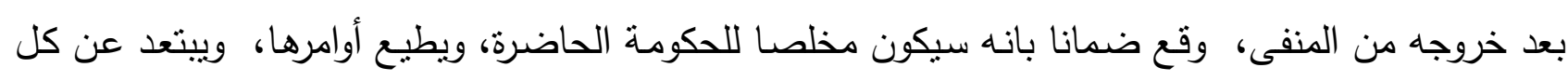

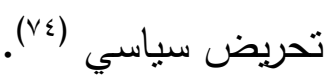
الهنداوي والملك فيصل الاول :-

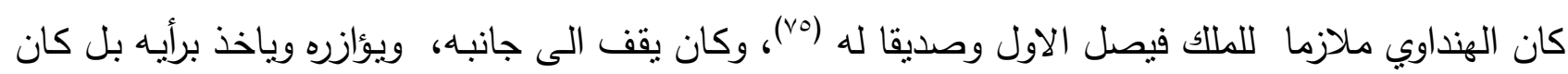

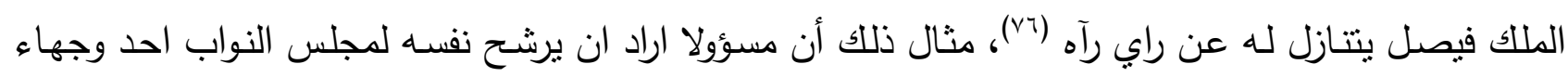
الكوت، وقد كان الهنداوي منصرفا في اللواء، فرفض مساعدته فقال له المسؤول ان الملك يرى ترشيحه، باجاجابه

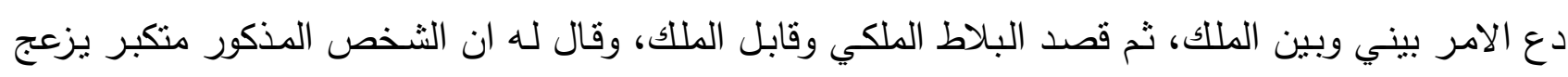

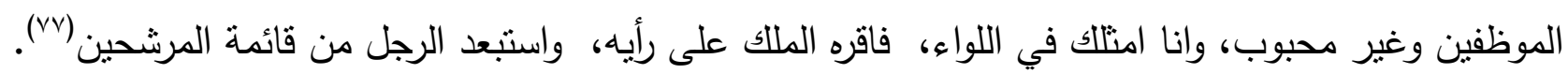

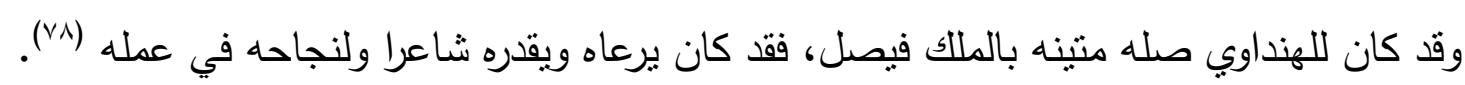

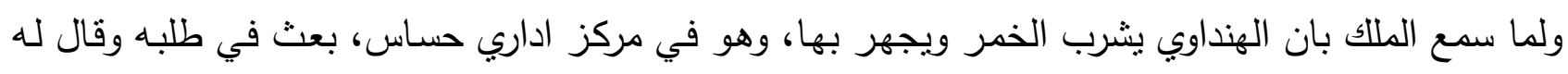

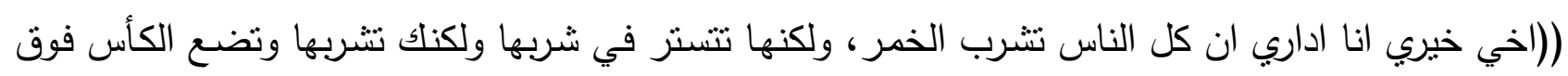

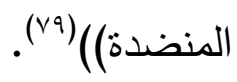

ثم قال له مداعبا ((خلي الكأس تحت المنضدة))(.).

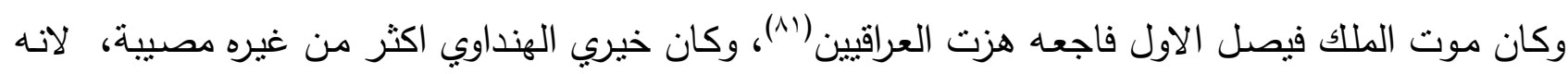

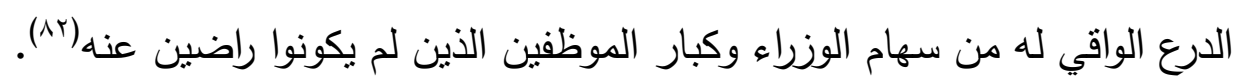

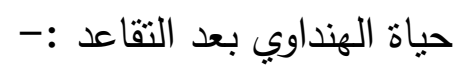
حين كان والد السيد خيري الهنداوي في قضاء الصويرة، اشتنرى ارضا زراعية في منطقة البغدادية(^r)، وما تزال

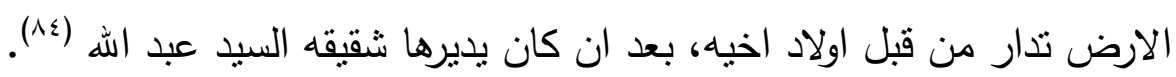

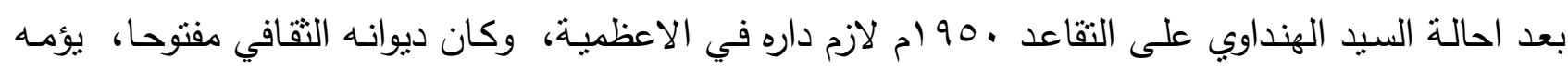

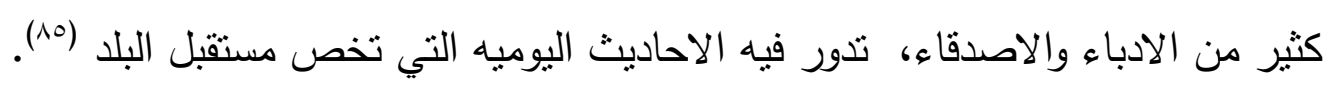

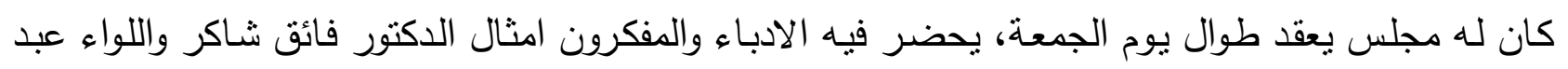

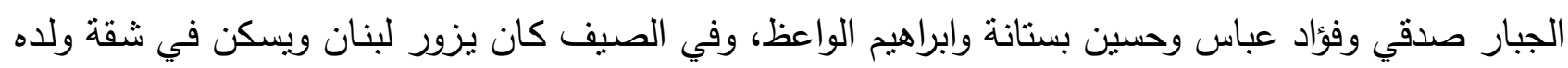

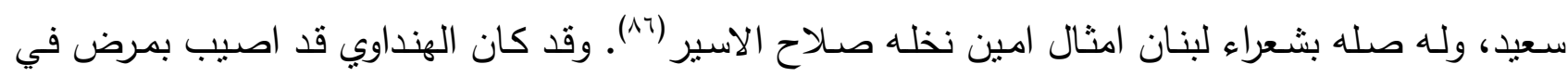

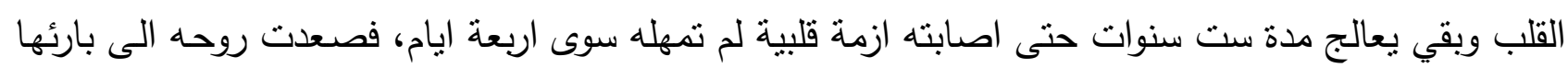

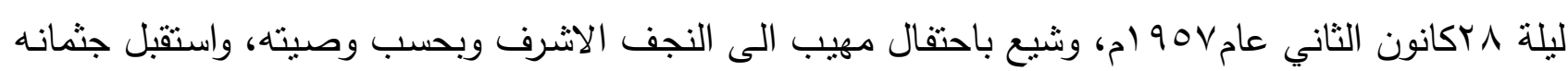

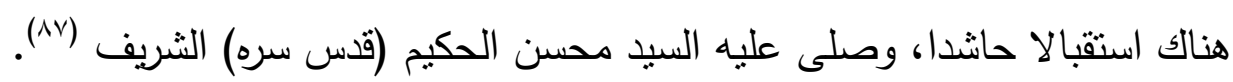
$\frac{\text { الخاتمة }}{r^{\prime}}$ 


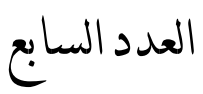

من خلال سبرة حباة خبري الهنداوي وجدت فيها ما يلفت النظر ، وخاصة في فكره الادبي والسياسي والوطني،

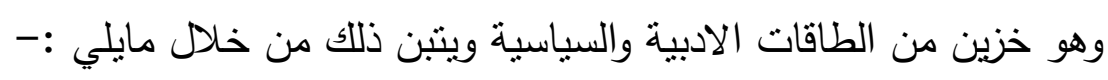

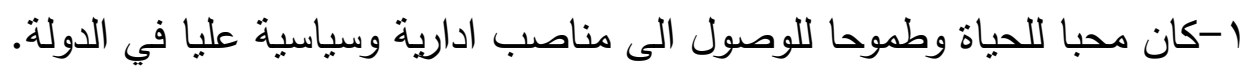
r- ب-كان شعره وادبه مشجعاً على الثورة.

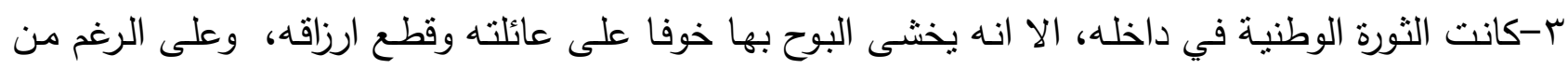

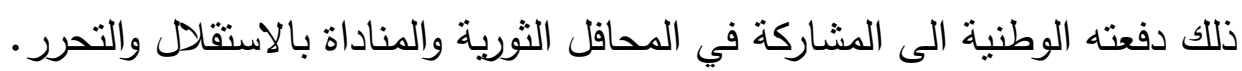

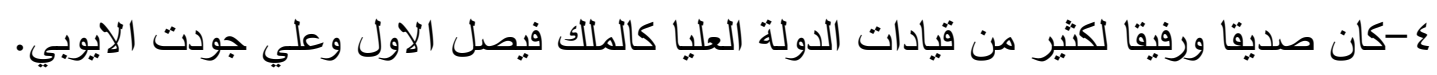

ه-كان من اوائل المطالبين بتحرير المرأة العراقية. 1-كان شخصية من شخصيات العراق القلقة المضطربة اجتماعيا، ووجدنا في مسيرته طموح العربي المتمثل بالرغبه في الاستقلال والتخلص من الاستعمار وحب الحرية والتمتع بها والتغني بأمجاد الامة العربية ووحدتها. الهوامش

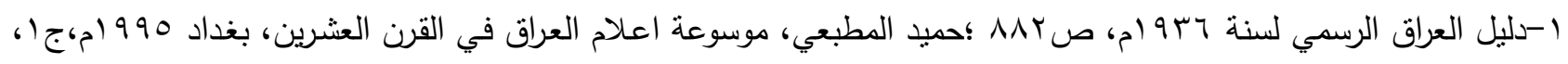

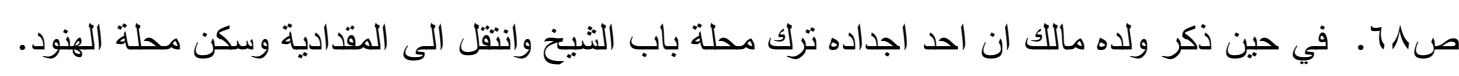

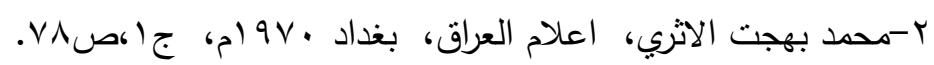

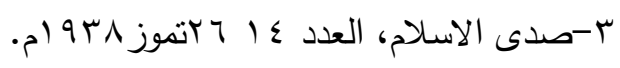

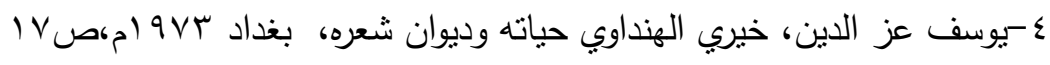
1- ج-حميد المطبعي، المصدر السابق.

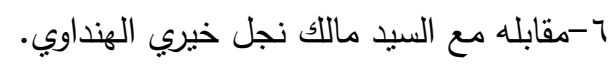

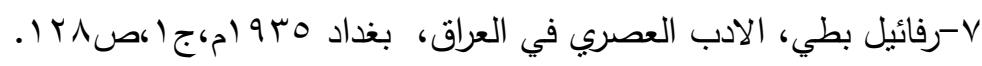

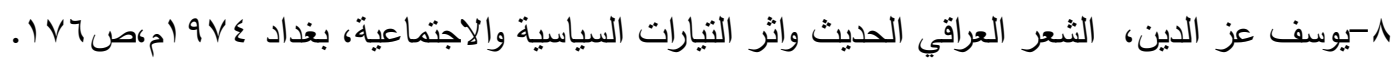

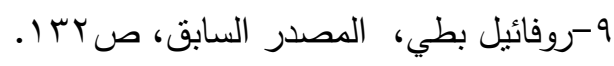
• ا-محمد بهجت الاثري، الدصدر السابق ؛حميد المطبعي، الدصدر السابق.

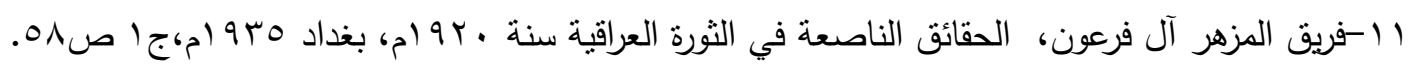

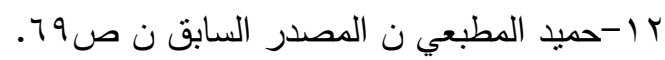

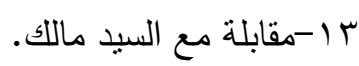

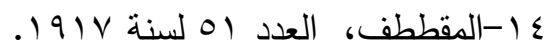
10 18 الكصدر نفسه.

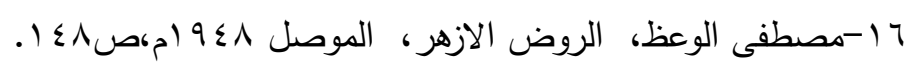

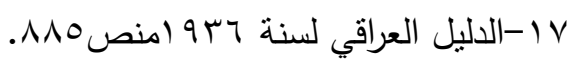

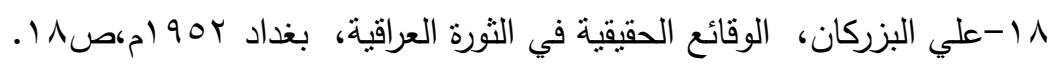

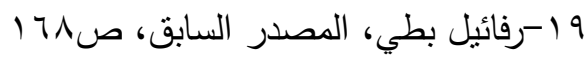

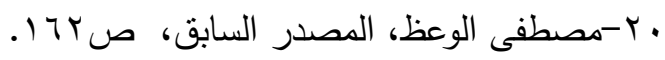


ا (Y-صدى الاسلام، العدد 9 لسنة ابو 19. r r-ملف خيري الهنداوي المحفوظة لدى عائلته.

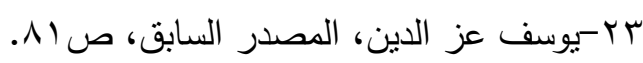
ـ ك-ملف خيري الهنداوي. هץ-يوسف عز الدين، المصدر السابق.

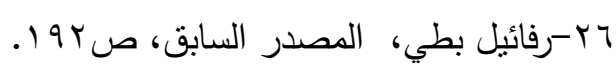

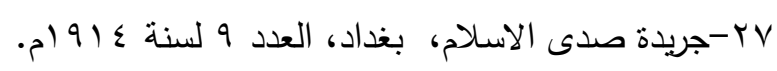

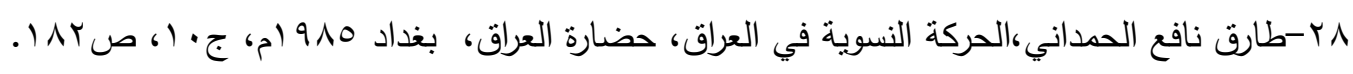

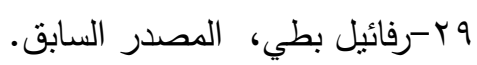

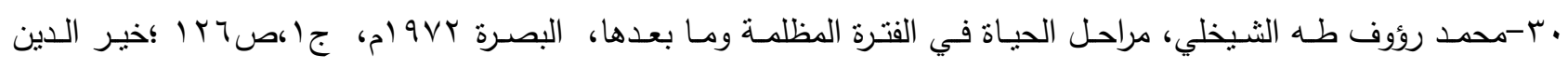

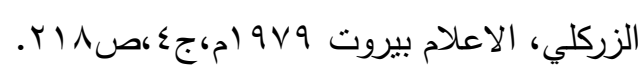

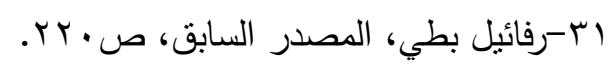

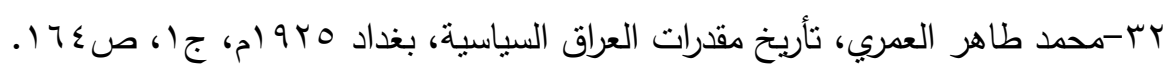

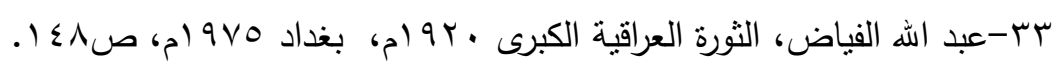
ع ب- المقططف، العدده لسنة 91919 ام.

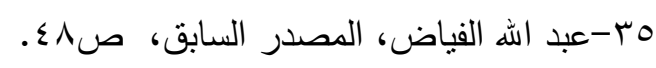

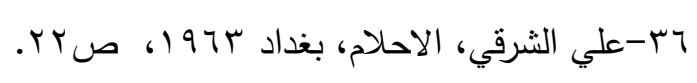

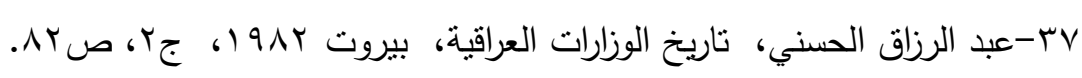

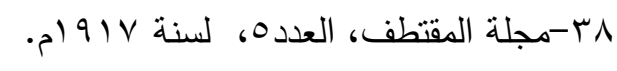

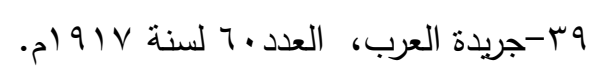

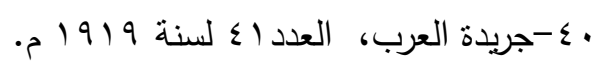

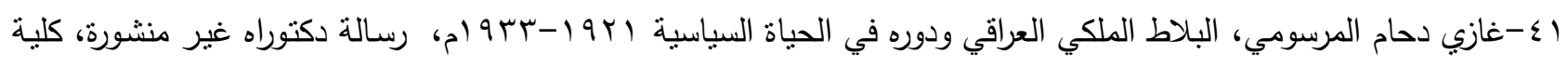

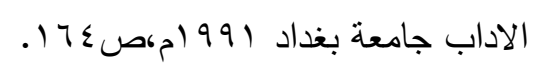
r r

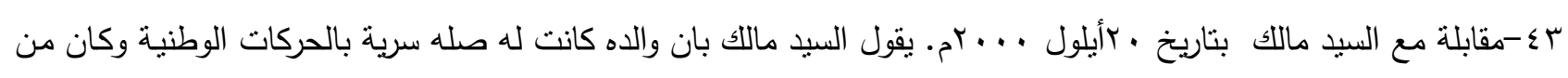

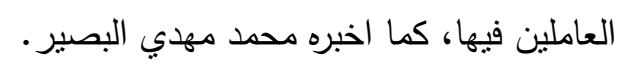

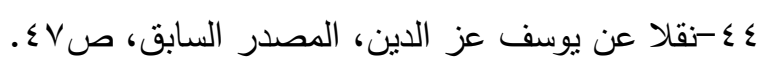
|

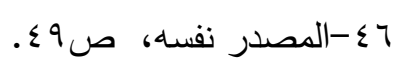
ي

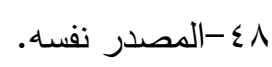
9 §-رسالة محفوظة في ملف الهنداوي. • م-نقلا عن يوسف عز الدين، المصدر السابق.

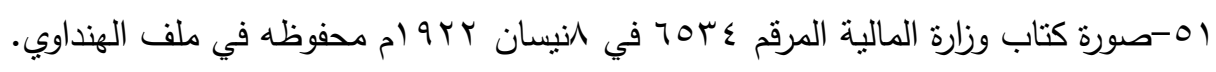

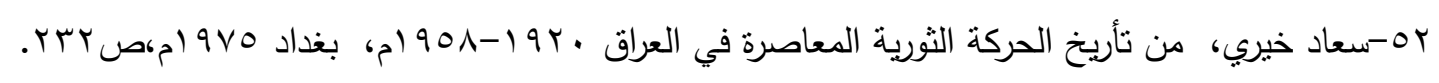


العدد السابع

\section{مجلة كلية التزبية}

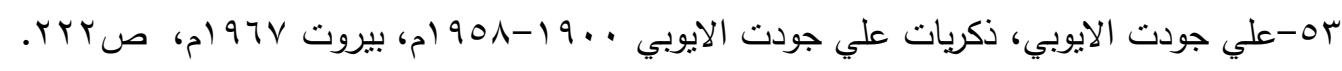
؟ه-الذرعة قياس مساحة الارض المزروعة لنقدير ضريبتها.

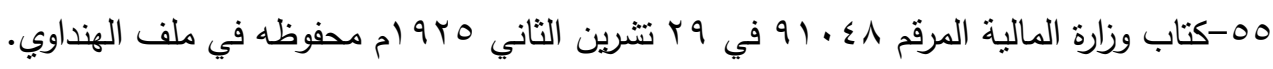

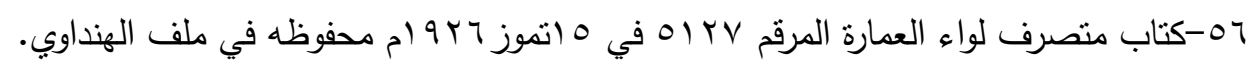

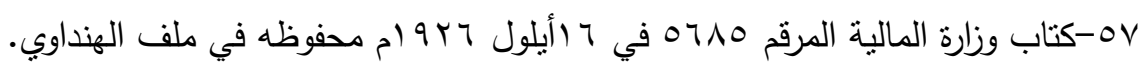

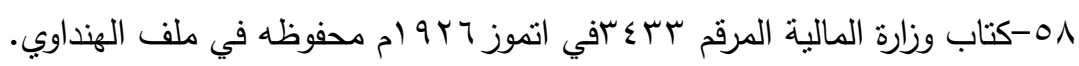

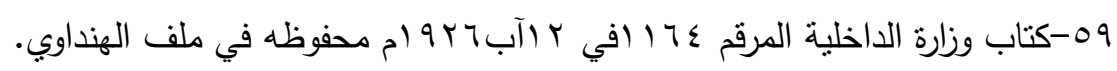

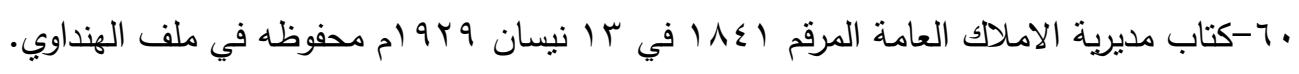

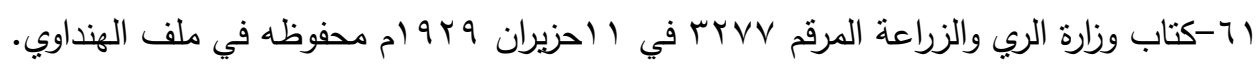
بآ-يوسف عز الدين، المصدر السابق. با ب-حسب ما مذكور في اضبارة السيد الهنداوي.

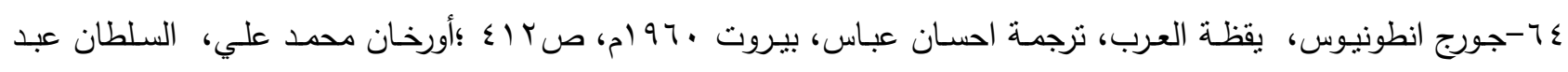
الحميد الثاني حياته واحداث عهده، بغداد 19NV

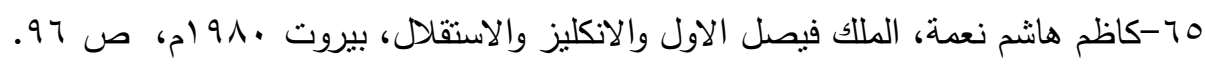

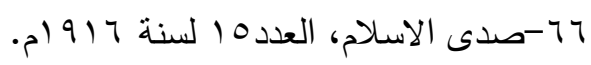

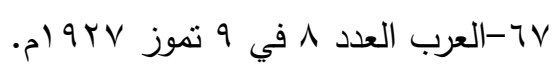
1 ب-૧ملفة السيد الهنداوي. 97-توفيق السويدي، مذكراتي نصف قرن من نأريخ العراق والقضية العربية، بيروت 979 ام، صرى ؛علي كاشف الغطاء، سعد

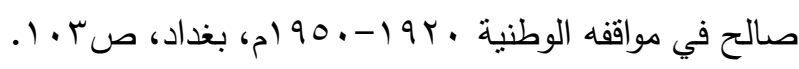
• Vيوسف عز الدين، المصدر السابق ن صـ 9.

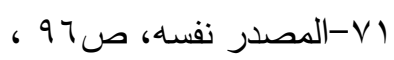
rill-V ع

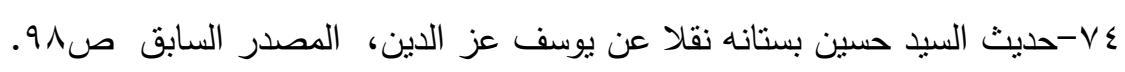

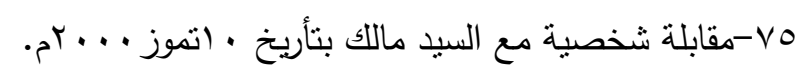

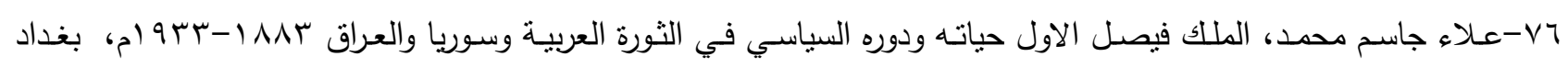
.910 . 99 .

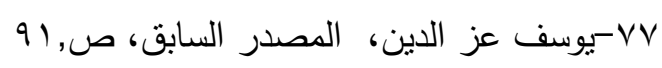
- المصدر نفسه.

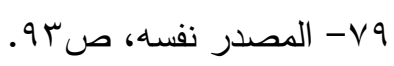
.

1 1-البغدادية هي ارض زراعية تقع جنوب قضاء الصويرة بمسافة مكم.

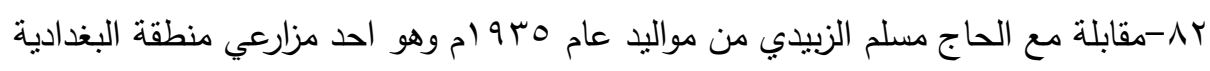

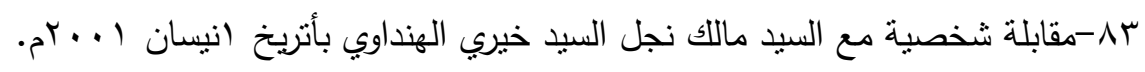

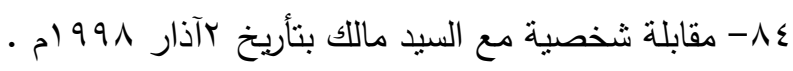




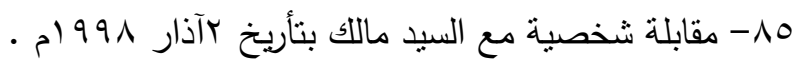
71/-يوسف عز الدين، المصدر السابق، ص 91. -AV

\section{المصادر والمراجع}

اولا:-المخطوطات.

ملف السيد خيري الهنداوي.

ثانيا:-المطبوعات الحكومية.

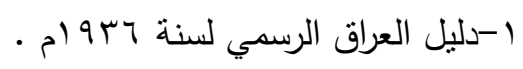

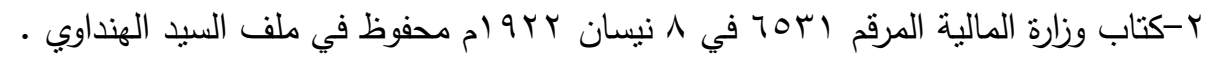
r ع

• = = = = = = = = = = = =

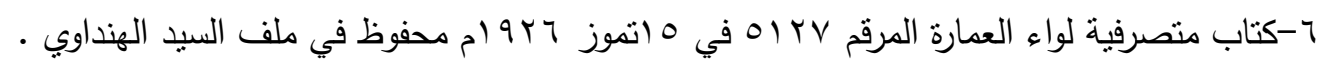

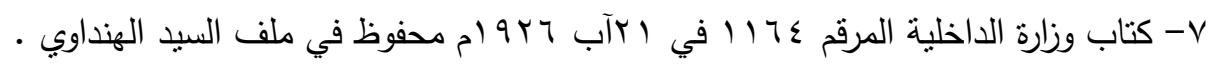

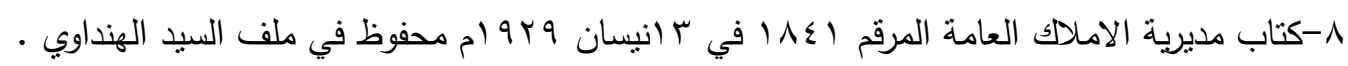

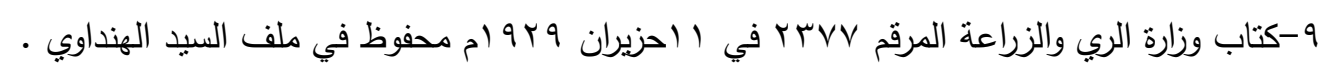
ثالثا:-الرسائل الجامعية.

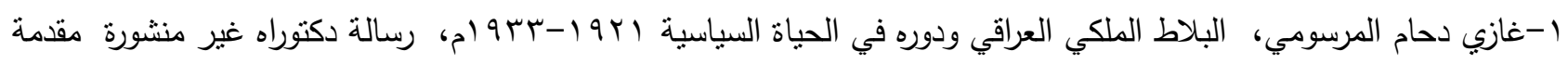

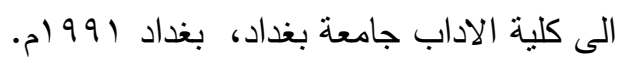
رابعا:-الكتب العربية والمعربة:-

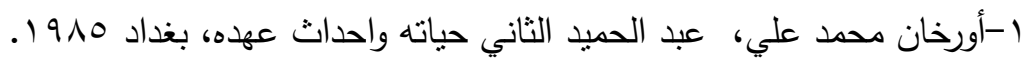

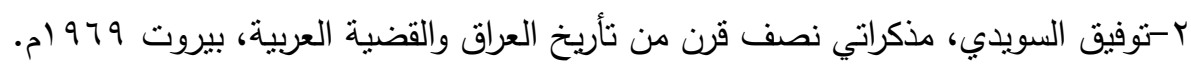

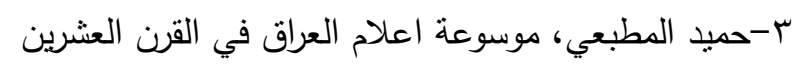

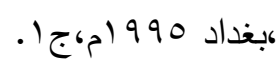

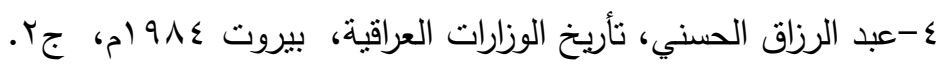

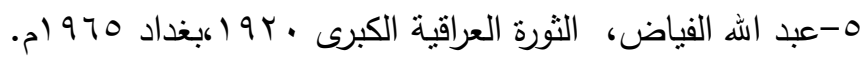

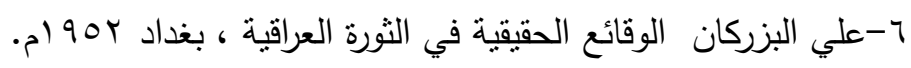

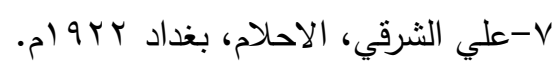

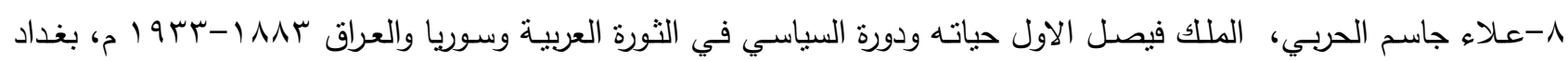
. 199 .

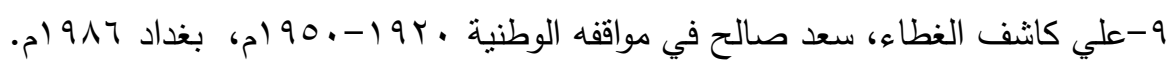

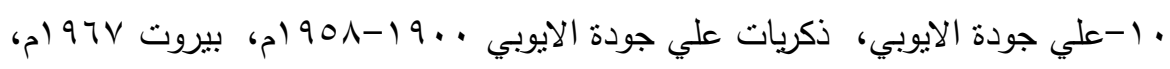

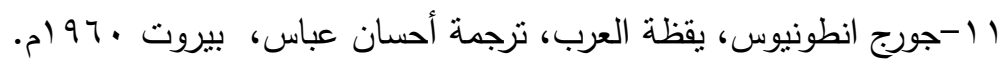

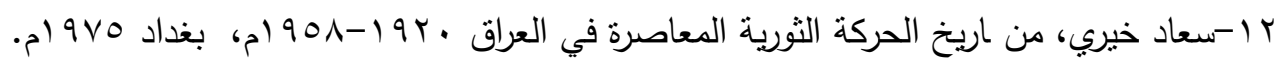


العدد السابح

محلة كلية التربية

ب ا-فريق مزهرآل فرعون، الحقائق الناصعة في الثورة العراقية، بغداد به امه، جا.

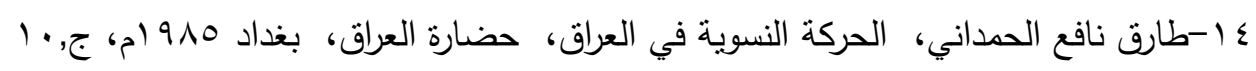

10-كاظم هانم النعمة، الملك فيصل الاول والانكليز والاستقلال، بيروت .919 ام.

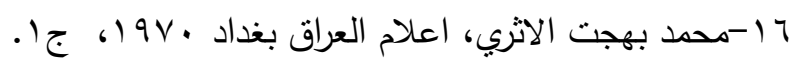

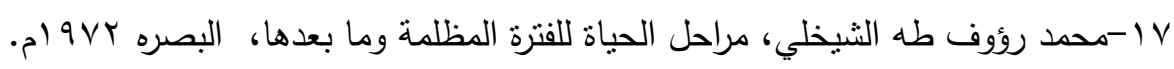

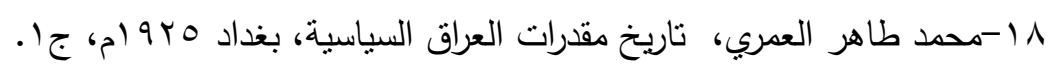

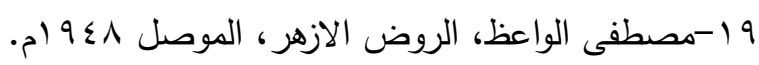

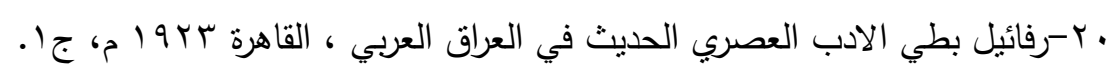

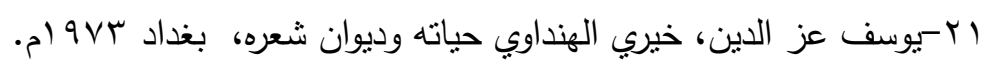

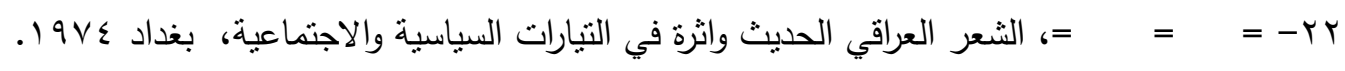
خامسا:-الدوريات :- (-) 1-المقتطف (مجلة). r- بدى الاسلام (جريدة ). ب-العرب (جريدة). سادسا:-المقابلات الثخصية. ا-بالسيد ماللك نجل خيري الهنداوي، عدة مقابلات.

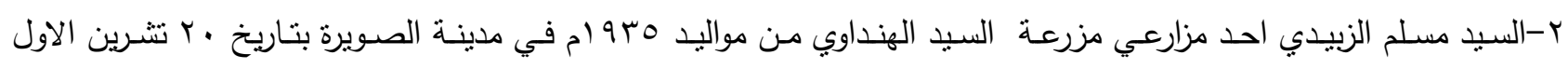
. 1999

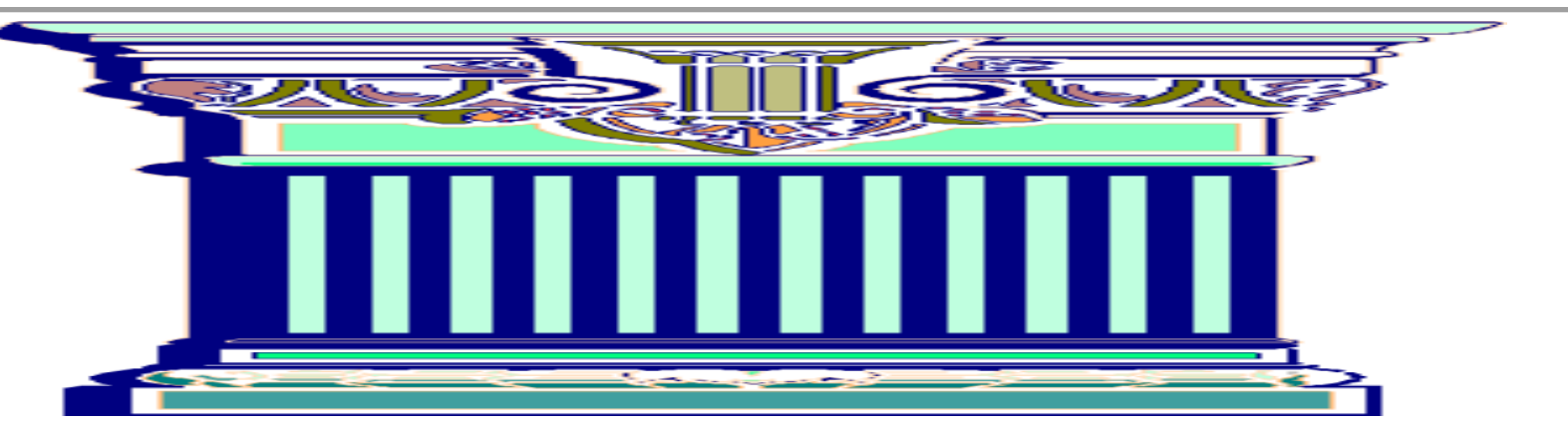

